\title{
ERUPTION AGE OF KANNABE VOLCANO USING MULTI-DATING: IMPLICATIONS FOR AGE DETERMINATION OF YOUNG BASALTIC LAVA FLOW
}

\author{
YORINAO SHITAOKA ${ }^{1}$, TAKESHI SAITO ${ }^{2}$, JUNJI YAMAMOTO ${ }^{3}$, MASAYA MIYOSHI ${ }^{4}$, \\ HIDEMI ISHIBASHI ${ }^{5}$ and TSUTOMU SODA ${ }^{6}$ \\ ${ }^{l}$ Department of Environmental Systems, Rissho University, Kumagaya 360-0194, Japan \\ ${ }^{2}$ Department of Geology, Shinshu University, Matsumoto 390-8621, Japan \\ ${ }^{3}$ The Hokkaido University Museum, Hokkaido University, Sapporo, 060-0810, Japan \\ ${ }^{4}$ Department of Science and Mathematics Education, University of Fukui, Fukui 910-8507, Japan \\ ${ }^{5}$ Department of Geosciences, Shizuoka University, Shizuoka, 422-8529, Japan \\ ${ }^{6}$ Institute of Tephrochronology for Nature and History Co., Ltd., Maebashi 371-0803, Japan
}

Received 23 April 2018

Accepted 25 March 2019

\begin{abstract}
We estimated the eruption age of Kannabe volcano, located in southwestern Japan. Although the eruption age had been estimated using tephrochronology and K-Ar dating, the precision of its age determination left some room for improvement. The latest eruption age of Kannabe volcano is well constrained by wide spread tephras to $c a$. 7.2-30 ka. We applied paleomagnetic dating to a basaltic lava and optically stimulated luminescence (OSL) dating to a soil layer, which are associated with the Kannabe volcano. The soil layer above the Kannabe scoria was newly dated to be $21 \pm 6 \mathrm{ka}$, as inferred from OSL dating. We also made paleomagnetic investigation to estimate the eruption age of the Kannabe basaltic lava. Paleomagnetic data of 23 rock samples from six locations in the Kannabe basaltic lava showed good mutual agreement. The average of remanent magnetizations yields declination of $0.3^{\circ}$ and inclination of $65.9^{\circ}$ with $95 \%$ confidence limit of $2.7^{\circ}$. This paleomagnetic direction with a relatively steep inclination is thought to be correlated with the paleomagnetic secular variation data of sediments in Lake Biwa at $c a .21 .5 \mathrm{ka}$. Based on that information from multi-dating, we inferred that the Kannabe volcano erupted at $c a$. $22 \mathrm{ka}$. This result presents profound scientific implications for the precise age determination of young basaltic lava flow, for which few dating methods exist.
\end{abstract}

Keywords: eruption age, Kannabe volcano, multi-dating, OSL dating, paleomagnetic dating.

\section{INTRODUCTION}

Volcanological studies require dating of volcanic ejecta to within several tens of kiloyears (ka). However, such dating presents difficulties because of adequate

Corresponding author: Y. Shitaoka

e-mail: shitaoka@ris.ac.jp methods are few and sampling problems are inherent. Radiocarbon $\left({ }^{14} \mathrm{C}\right)$ dating is applicable for ages from several hundred years to a few tens of thousands of years. Nevertheless, the possible occurrence of contaminants such as mold, mildew, and fungus on samples complicates the interpretation of dating results. Moreover, during ${ }^{14} \mathrm{C}$ dating, one frequently encounters difficulties in collecting datable organic material in volcanic contexts. Although thermoluminescence (TL) and optically stimulated luminescence (OSL) dating have been used widely 
for archaeological studies, this method entails difficulties because it requires quartz for accurate dating (e.g., Tsukamoto et al., 2011). Applying both TL and OSL dating is possible even for basic lava. Actually, TL dating using quartz xenoliths in scoria (Rufer et al., 2012) and quartz xenocrysts in basaltic lava (Shitaoka et al., 2014) were performed. There is, however, no quartz in Kannabe scoria, as described below.

Paleomagnetic dating represents an alternative. Volcanic materials deriving from eruption can acquire stable thermoremanent magnetization (TRM) during their initial cooling. The Earth's magnetic field changes its direction by several degrees to a few tens of degrees over timescales of 100-1,000 years, which represents secular variation. Paleosecular variation (PSV) can thereby be reconstructed, as described in numerous earlier reports of the literature (e.g., Jackson and Finlay, 2007). Comparison of the PSV with the paleomagnetic direction inferred from TRM of volcanic materials can suggest the age at which magnetic minerals in the materials acquired the remanence. Paleomagnetic age determination can be done directly from the material for which the age is sought.

One shortcoming inherent in the method, however, has often troubled us and other researchers: PSV varies at most by a few tens of degrees around a direction that is generally derived from the axial dipole component of the Earth's magnetic field. Even if the paleomagnetic direction could be determined with high accuracy, the paleomagnetic age could not be identified uniquely because several candidates for age can be inferred from paleomagnetic data. Ascertaining the correct age using paleomagnetic methods alone is difficult. Age estimation based on PSV must be combined with other dating techniques.

An almost perfect target as an attempt for a combined age estimation is Kannabe volcano (Fig. 1), located $120 \mathrm{~km}$ west of Lake Biwa. In fact, PSV data for the last 40 ka have been reported from the Lake Biwa sediment (Hayashida et al., 2007). Although the latest eruption age of Kannabe volcano has been estimated using K-Ar dating and loess stratigraphy (Furuyama et al., 1993), the age-determination precision can be improved.

We attempted paleomagnetic dating to estimate the Kannabe volcano eruption age. Furthermore, we applied OSL dating to sediments associated with the Kannabe scoria cone.

\section{GEOLOGICAL SETTING}

Kannabe volcano in southwestern Japan (N 35³0'20.1', E 13440'29.0”), the youngest volcano in Kannabe monogenetic volcano group (Fig. 1), has been the locus of alkali basalt volcanism since $c a .12 \mathrm{Ma}$ after the opening of Japan Sea (e.g., Kimura et al., 2005). Although the Philippine Sea plate subducts northwestward beneath the southwestern Japan arc, no seismic slab of the subducting plate is observed beneath this volcano. Tomographic evidence indicates that a low-velocity man- tle zone exists beneath it at depths of $c a .60-200 \mathrm{~km}$, which is interpreted as upwelling asthenosphere and as a primary source region for magmatism (Nakajima and Hasegawa, 2007).

The Kannabe monogenetic volcano group comprises seven scoria cones (Nishiki, Yamanomiya, Buri, Otsukue, Tada, Kiyotaki, and Kannabe volcanoes) and one scoria bed (Nishibashi-kita) (Kawamoto, 1990; Furuyama et al., 1993). Basement rocks of these volcanoes are Miocene sediments and rhyolitic-dacitic tuff (Wadatsumi and Matsumoto, 1958). The volcanic activity of Kannabe volcano is characterized by the eruption of a lava flow (Kannabe lava flow) after scoria cone formation (Kannabe scoria cone; see Fig. 1). Furuyama (1973) reported Kannabe lava as divided into four lava flow units based on geomorphologicalogical features: Hidaka, Arakawa, Jyugo, and Shiwagano. We designate lava of the Kannabe volcano as "Kannabe lava", as Kawamoto (1990) did in earlier work. Furuyama (1973) and Kawamoto (1990) described Kannabe lava as directly overlying Kannabe scoria.

These volcanoes erupted alkali olivine basalts with phenocrysts of olivine and plagioclase (e.g., Kawamoto, 1990; Furuyama et al., 1993). Kawamoto (1990) showed that volcanic ejecta from the Kannabe monogenetic volcano group, except for Kannabe volcano, are covered by an Aira-Tn ash bed (AT, $30.009 \pm 0.189 \mathrm{ka}$; Smith et al., 2013, ca. $30 \mathrm{ka}$ ). The following reported $\mathrm{K}-\mathrm{Ar}$ ages of these volcanoes are consistent with the stratigraphic relation: Nishiki volcano, 0.685-0.741 Ma; Otsukue volcano, $0.218 \pm 0.008 \mathrm{Ma}$; Buri volcano, $0.173 \pm 0.009 \mathrm{Ma}$; Tada volcano, $0.103 \pm 0.004 \mathrm{Ma}$; and Kiyotaki volcano, $0.055 \pm 0.007 \mathrm{Ma}$; Furuyama et al., 1993). Although Furuyama et al. (1993) reported the K-Ar ages of the rock samples from Kannabe lava as $0.022 \pm 0.015 \mathrm{Ma}$,

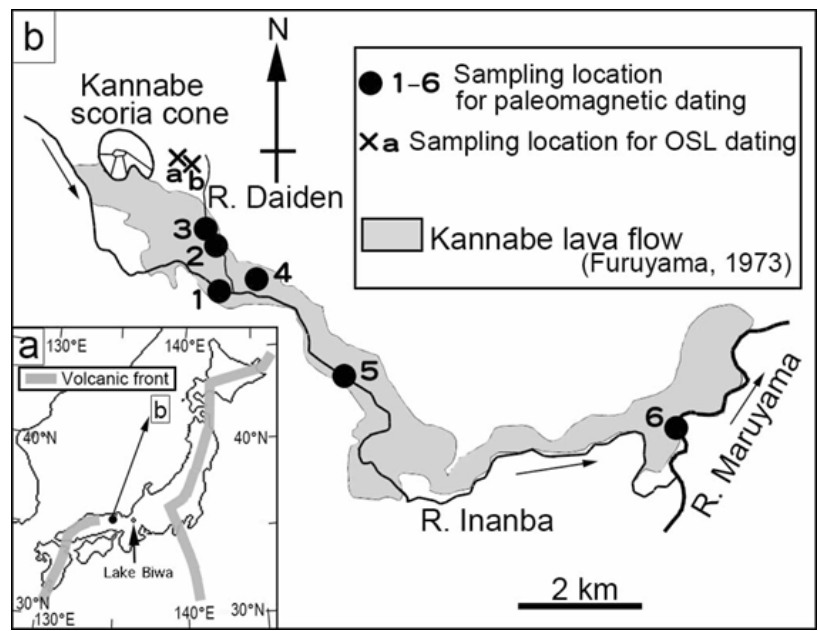

Fig. 1. Index (a) and locality (b) maps. Sampling locations of Kannabe scoria cone in southwestern Japan for paleomagnetic samples (locs. 1-6) and OSL dating (loc. a). Outcrop of loc. b is shown as AT tephra under Kannabe scoria (see Fig. 2). 
$0.026 \pm 0.009 \mathrm{Ma}, 0.072 \pm 0.012 \mathrm{Ma}, 0.086 \pm 0.014 \mathrm{Ma}$, two of them are considerably older than the AT tephra (ca. $30 \mathrm{ka})$, which underlies Kannabe Scoria (0.072 and

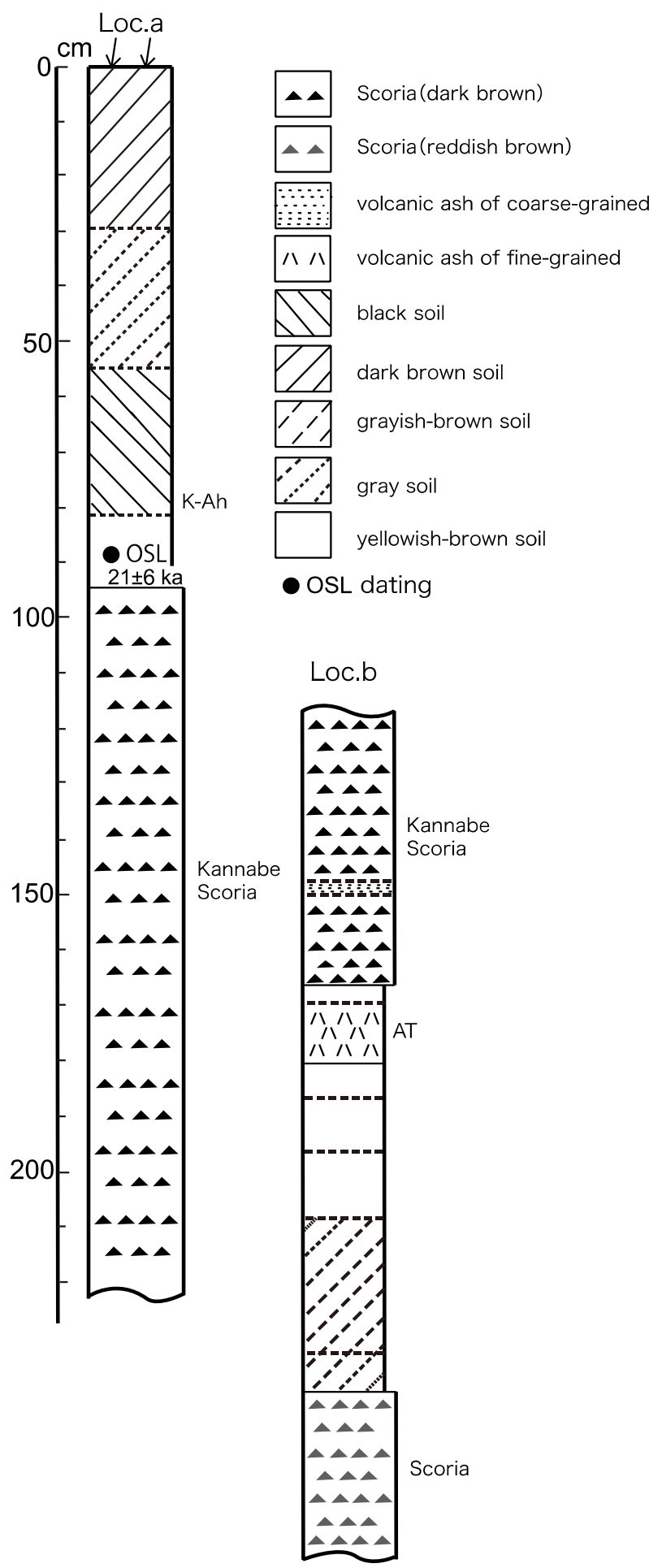

Fig. 2. Geological columnar sections in locs. a and b of Fig. 1. Closed circle show sampling positions for OSL dating. The estimated OSL age is also shown.
$0.086 \mathrm{Ma})$. This inconsistency is probably attributable to excess ${ }^{40} \mathrm{Ar}$ (Furuyama et al., 1993). It is noteworthy that these young $\mathrm{K}-\mathrm{Ar}$ ages were measured from whole-rock samples of the lava using the isotope dilution method, which is thought to be less reliable than recent $\mathrm{K}-\mathrm{Ar}$ dating of groundmass samples using the unspiked method. Kawamoto (1990) inferred that volcanic ejecta from Kannabe volcano are sandwiched between AT ( $c a .30 \mathrm{ka})$ and Kikai-Akahoya ash (K-Ah, 7,165-7,303 cal. ka BP; Smith et al., 2013, ca. 7.2-7.3 ka) beds (Fig. 2).

The Kannabe lava sample 4 (Fig. 3) has crystal contents of 5 vol.\%, including phenocrysts of plagioclase (3 vol.\%; $<2 \mathrm{~mm}$ ) and olivine ( 2 vol.\%; $<1.5 \mathrm{~mm})$. The olivine is euhedral or subhedral, sometimes exhibiting a skeletal texture. Clear euhedral plagioclase coexists with minor dusty anhedral plagioclase. The groundmass shows an intergranular texture with microlites of pyroxene, olivine, plagioclase, and opaque minerals. Quartz was not observed, even as a xenocryst.

\section{ANALYTICAL PROCEDURES}

\section{Paleomagnetic dating}

Paleomagnetic samples were taken from six outcrops of Kannabe lava flows. Sampling locations are presented in Fig. 1. Twenty-three lava clasts were oriented using a magnetic compass. In the laboratory, specimens of $25 \mathrm{~mm}$ diameter and $22 \mathrm{~mm}$ height were cut from the orientated lava clasts. The natural remanent magnetization (NRM) of each specimen was measured using a spinner magnetometer (SMD-88; Natsuhara Giken Co. Ltd.). Specimens were demagnetized thermally (TDS-1; Natsuhara Giken Co. Ltd.) and magnetically (DEM-97; Natsuhara Giken Co. Ltd.). From demagnetization results displayed as vector end-point diagrams (Zijderveld, 1967), we ascertained the components of remanent magnetization. Then we applied principal component analysis to each component (Kirschvink, 1980). A stable magnetic

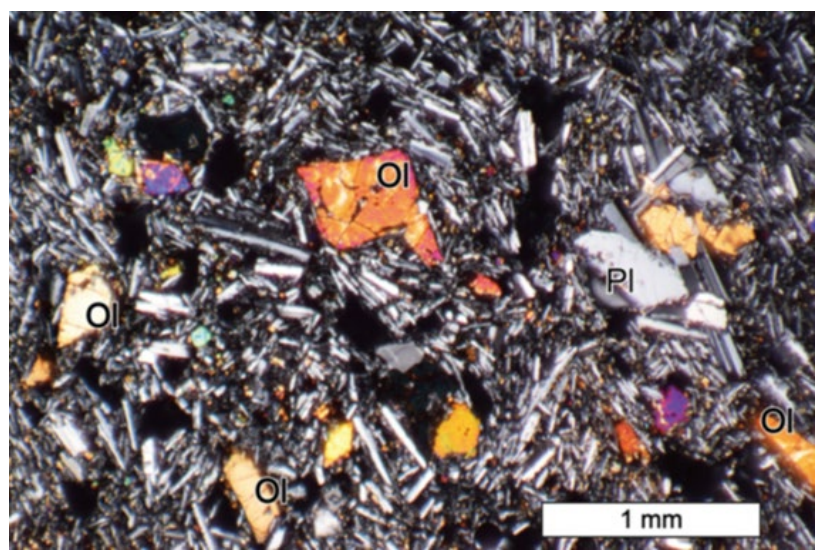

Fig. 3. Optical photomicrograph of a Kannabe lava sample 4 under crossed polarizer: Ol, olivine; PI, plagioclase. 
component was defined as follows: (1) a linear segment consisting of more than three vector end points; and (2) maximum angular deviation (MAD) of less than $5^{\circ}$.

\section{OSL dating}

An OSL sample was collected at loc. a (N 35³0'20.9', E 13441'02.2') in Fig. 1. Minerals in the collected sample were separated into sand and silt matter by wet sieving in water. After silt matter was treated with $10 \%$ hydrogen peroxide for $16 \mathrm{hr}$, fine silt (fine grain; FG, $c a$. 4-10 $\mu \mathrm{m}$ ) was separated using Stokes' law of setting in acetone. After fine silt of the sample was treated with $10 \%$ hydrochloric acid for 90 min, it was immersed in $20 \%$ hydrofluorosilicic acid for 8 days to separate the fine-grained quartz. The quartz extract purity was verified using infrared stimulation luminescence (IRSL) measurement (Shitaoka and Nagatomo, 2013). Conditions used for IRSL measurements to check the feldspar mixture were $60^{\circ} \mathrm{C}$ reading temperature with infrared stimulation power of $86.9 \mathrm{~mW} / \mathrm{cm}^{2}$. It was an IRSL signal at the instrumental background level.

The OSL measurements were taken using an OSL reader (NRL-99-OSTL; Neoark Corp.) equipped with an array of 32 blue LEDs $\left(470 \mathrm{~nm}, 18.1 \mathrm{~mW} / \mathrm{cm}^{2}\right)$ (Nagatomo et al., 2007; 2009). The OSL from a sample was detected using a photomultiplier tube (R1140P; Hamamatsu Photonics K.K.) housed in a cooling unit, through two condensing lenses and a glass filter ( $2 \mathrm{~mm}$, Hoya U-340; Kenko Tokina Corp.). Irradiation was conducted using a Risø ${ }^{90} \mathrm{Sr}-{ }^{90} \mathrm{Y}$ beta source (dose rate $4.8 \mathrm{~Gy} / \mathrm{min}$ ). We used OSL dating with a single aliquot regenerative-dose protocol (SAR, Table 1; Murray and Wintle, 2000). To select an appropriate preheating condition using the SAR protocol, a preheat plateau test was conducted between $220^{\circ} \mathrm{C}$ and $280^{\circ} \mathrm{C}$ for $60 \mathrm{~s}$ at an interval of $20^{\circ} \mathrm{C}$ (Fig. 4). Because a plateau was obtained across the entire preheat range of $220-260^{\circ} \mathrm{C}$, we selected $240^{\circ} \mathrm{C}$.

The annual dose (dose rate) was measured using a high-resolution gamma-ray spectrometer. The concentrations of ${ }^{238} \mathrm{U},{ }^{232} \mathrm{Th}$, and ${ }^{40} \mathrm{~K}$ in the soil sample were analyzed using a Ge gamma-ray detector (EGSP 8785; Eurisys Mesures). The annual dose was calculated using the

Table 1. Protocol for SAR measurement.

\begin{tabular}{lll}
\hline Step & Treatment & Observed \\
\hline 1 (a) & Give dose, $D_{i}$ & - \\
\hline 2 & Preheat $\left(240^{\circ} \mathrm{C}\right.$ for $\left.60 \mathrm{~s}\right)$ & - \\
\hline 3 & Stimulate for $100 \mathrm{~s}$ at $125^{\circ} \mathrm{C}$ & $L_{i}$ \\
\hline 4 & Give test dose, $5 \mathrm{~Gy}$ & - \\
\hline 5 & Cut heat $\left(160^{\circ} \mathrm{C}\right)$ & - \\
\hline 6 & Stimulate for $100 \mathrm{~s}$ at $125^{\circ} \mathrm{C}$ & $T_{i}$ \\
\hline 7 & Stimulate for $40 \mathrm{~s}$ at $250^{\circ} \mathrm{C}$ & - \\
\hline 8 & Return to 1 & - \\
\hline
\end{tabular}

Step 1: For the natural sample, $i=0$ and $D_{0}=0$ Gy. dose-rate conversion factors reported by Guérin et al. (2011). Present water contents of samples were used. Water contents (assuming an uncertainty of $\pm 10 \%$ ) were estimated as the water weight over the dry soil weight. We assumed that environmental changes relative to the water content of the sample sediment were unlikely. Contributions of the cosmic dose rate to the annual dose were assumed according to methods proposed in earlier reports by Prescott and Hutton (1994), Nagatomo et al. (2009), and Shitaoka et al. (2009).

\section{RESULTS}

\section{Paleomagnetic direction}

Results of demagnetization experiments show that all specimens had strong and stable magnetizations, with $\mathrm{NRM}$ intensities of $1.0-5.0 \times 10^{-3} \mathrm{Am}^{2} / \mathrm{kg}$. Magnetization of ten samples decayed linearly toward the origin. Single magnetic components with low MAD of less than $0.5^{\circ}$ were obtained (Fig. 5a). Six samples showed noisy trajectories with considerable scatter (Fig. 5b). A trend of data points toward the origin is apparent, with identified single magnetic components, although they have higher MAD of about $1-5^{\circ}$. These magnetic components were adopted as thermal remanent magnetization (TRM) acquired during initial cooling of the lava. Four samples have two magnetic components (Fig. 5c). Magnetic components removed at lower demagnetization levels are not well resolved and are distributed randomly. We interpret the components as showing viscous remanent magnetization (VRM) acquired after lava emplacement. However, magnetic components removed at higher demagnetization levels showed a straight line toward the origin. Their

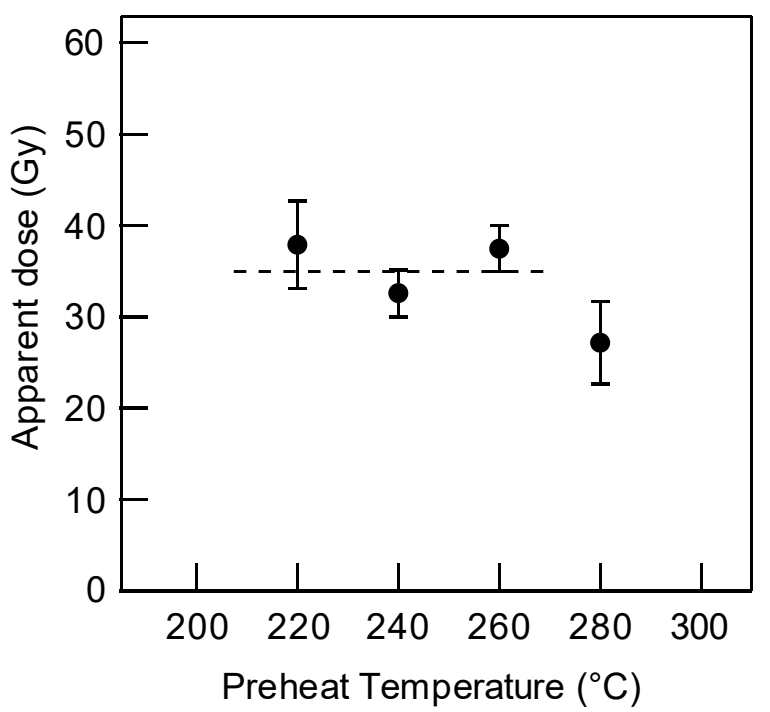

Fig. 4. Preheat temperature plateau measurement. Averages of three aliquots are shown at the respective temperatures. A preheating plateau is apparent at $220-260^{\circ} \mathrm{C}$. 


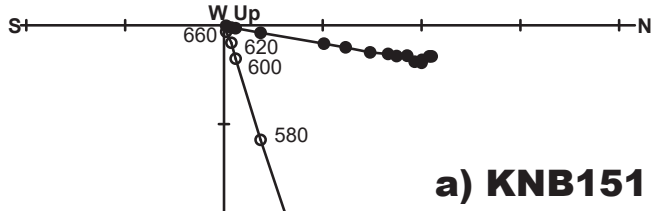

a) KNB151
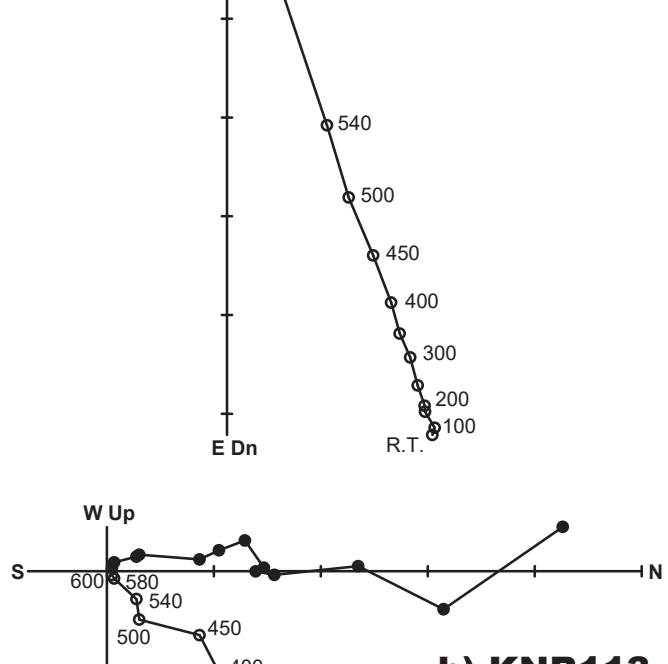

b) KNB113
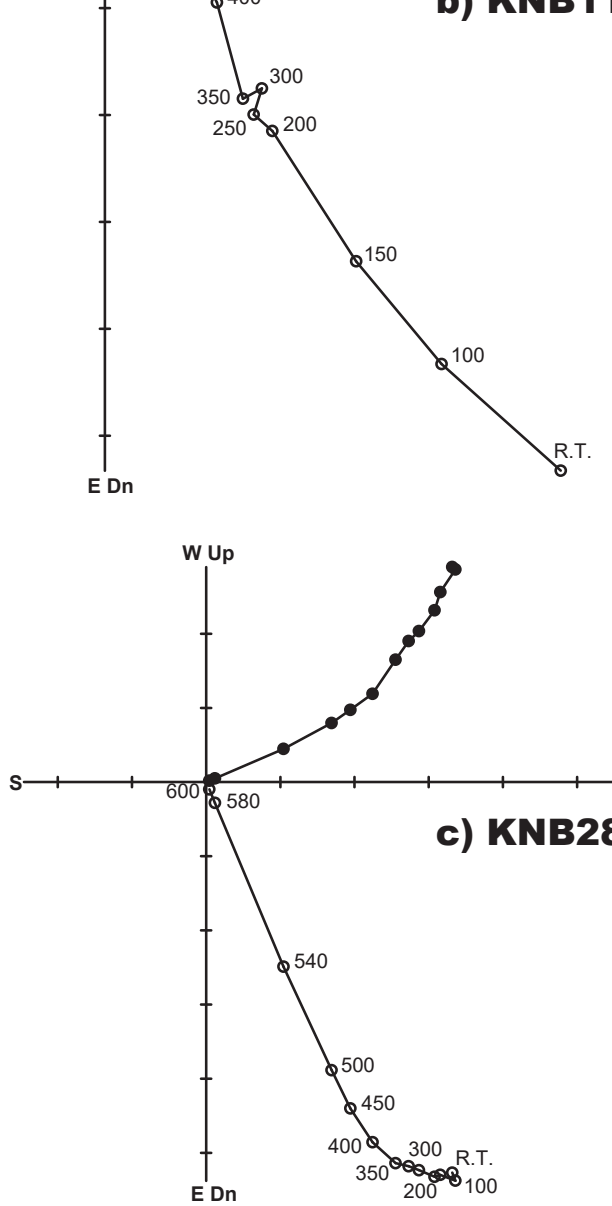

Fig. 5. Vector end-point diagrams of demagnetization results for typical Kannabe samples. Solid and open circles respectively represent projections onto the horizontal and $\mathrm{N}-\mathrm{S}$ vertical planes: (a) one magnetic component with smooth decay to the origin; (b) noisy trajectories with scatter; and (c) two magnetic components. directions are almost parallel to the directions of magnetic components from the other samples. Therefore, the components removed at higher demagnetization levels are adopted as TRM (Table 2).

Magnetic components derived from TRM at the origin show better grouping of the direction (Fig. 6). The mean directions are $D=0.3^{\circ}, \quad I=65.9^{\circ}, \quad \alpha_{95}=2.7^{\circ}, \quad$ and $k=126.5$. The inclination is steeper than the present Earth's magnetic field direction at this location $\left(49.7^{\circ}\right)$, which also suggests the remanence origin as TRM, not VRM. The steep inclination is characteristic of Kannabe lava, consistent with previous studies: $66.6^{\circ}$ reported by Torii et al. (1978) and $66.3^{\circ}$ by Morinaga et al. (2000).

\section{OSL dating}

Sensitivity-corrected OSL signals were calculated by dividing $L_{\mathrm{i}}$ by the respective $T_{\mathrm{i}}\left(\right.$ i.e., $\left.L_{\mathrm{i}} / T_{\mathrm{i}}\right)$ using software (IGOR Pro version 6.03; Wavemetrics, Inc.). The SAR protocol consists of a series of regenerative and test dose measurements to create a sensitivity-corrected growth curve onto which the sensitivity-corrected natural OSL signal $\left(L_{\text {natural }} / T_{\text {natural }}\right)$ is projected. The paleodose value is obtained from the point of intercept, which is then interpolated onto the dose axis (Fig. 7). The values of the paleodose and the error of each aliquot were estimated using measurement conditions reported by Wintle and Murray (2006) and found using a Monte Carlo method (Duller, 2007). Of 15 aliquots, 6 aliquots were rejected, as estimated by extrapolation over a 45 Gy regeneration dose. A radial plot (Vermeesch, 2009) of paleodoses is presented in Fig. 8. The overdispersion value was

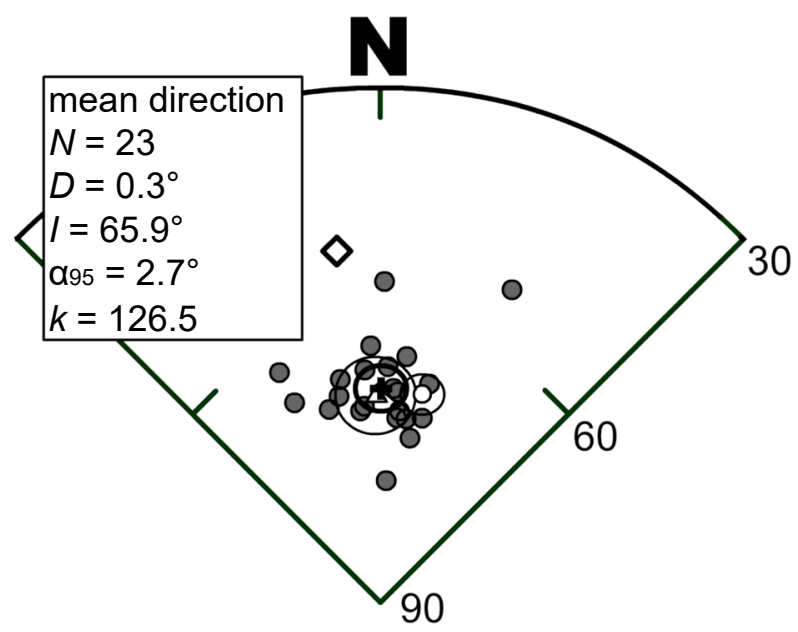

Fig. 6. Equal-area projection onto the lower hemisphere of magnetic components (solid circles) showing the mean direction (cross), its $95 \%$ confidence circle and present Earth's magnetic field (square) around the studied area are shown. The mean direction and its 95\% confidence limit from Torii et al. (1978) and from Morinaga et al. (2000) are also shown respectively as open triangles and open circles. 
Table 2. Sampling localities and demagnetization results.

\begin{tabular}{|c|c|c|c|c|c|c|c|}
\hline \multicolumn{3}{|c|}{ Sampling locality } & \multirow[b]{2}{*}{ Sample name } & \multirow{2}{*}{$\begin{array}{l}\text { Demagnetization } \\
\text { methods }\end{array}$} & \multicolumn{3}{|c|}{ Demagnetization results } \\
\hline Number & Latitude & Longitude & & & $\operatorname{Dec}\left({ }^{\circ}\right)$ & $\operatorname{Inc}\left({ }^{\circ}\right)$ & $\operatorname{MAD}\left({ }^{\circ}\right)$ \\
\hline \multirow[t]{5}{*}{1} & $35^{\circ} 29^{\prime} 9.599^{\prime \prime}$ & $134^{\circ} 41^{\prime \prime 45.999^{\prime \prime}}$ & 264 & thermally & 5.6 & 68.2 & 0.3 \\
\hline & & & 272 & thermally & 12.8 & 64.7 & 0.4 \\
\hline & & & 282 & thermally & -23.3 & 65.5 & 0.2 \\
\hline & & & 291 & thermally & -11.3 & 66.3 & 0.3 \\
\hline & & & 301 & thermally & -4.8 & 67.8 & 0.8 \\
\hline \multirow[t]{3}{*}{2} & $35^{\circ} 29^{\prime} 27.599^{\prime \prime}$ & $134^{\circ} 41^{\prime} 34.800^{\prime \prime}$ & 191 & thermally & 22.9 & 51.3 & 0.4 \\
\hline & & & 201 & thermally & -3.8 & 63.7 & 1.4 \\
\hline & & & 211 & thermally & 2.8 & 65.9 & 0.5 \\
\hline \multirow[t]{4}{*}{3} & $35^{\circ} 29^{\prime} 31.199^{\prime \prime}$ & $134^{\circ} 41^{\prime} 34.800^{\prime \prime}$ & 222 & thermally & -5.9 & 68.3 & 0.3 \\
\hline & & & 231 & thermally & -14.7 & 67.5 & 0.4 \\
\hline & & & 241 & thermally & 12.9 & 68.7 & 0.2 \\
\hline & & & 251 & thermally & -23.7 & 61.6 & 1.8 \\
\hline \multirow[t]{4}{*}{4} & $35^{\circ} 29^{\prime} 16.799^{\prime \prime}$ & $134^{\circ} 42^{\prime} 3.599^{\prime \prime}$ & 41 & magnetically & 2.0 & 63.4 & 1.0 \\
\hline & & & 161 & thermally & 6.2 & 62.1 & 1.8 \\
\hline & & & 171 & thermally & -10.1 & 64.5 & 1.3 \\
\hline & & & 181 & thermally & 6.0 & 68.9 & 1.2 \\
\hline \multirow[t]{5}{*}{5} & $35^{\circ} 28^{\prime} 30.000^{\prime \prime}$ & $134^{\circ} 42^{\prime} 46.799^{\prime \prime}$ & 12 & magnetically & 4.9 & 69.1 & 0.9 \\
\hline & & & 31 & magnetically & 4.7 & 66.2 & 0.8 \\
\hline & & & 131 & thermally & 8.0 & 69.1 & 0.3 \\
\hline & & & 145 & thermally & 2.9 & 76.3 & 0.2 \\
\hline & & & 151 & thermally & 10.3 & 71.2 & 0.4 \\
\hline 6 & $35^{\circ} 28^{\prime} 8.400^{\prime \prime}$ & $134^{\circ} 46^{\prime} 37.199^{\prime \prime}$ & $\begin{array}{l}113 \\
121\end{array}$ & $\begin{array}{l}\text { thermally } \\
\text { thermally }\end{array}$ & $\begin{array}{r}0.8 \\
-2.1\end{array}$ & $\begin{array}{l}53.5 \\
61.0\end{array}$ & $\begin{array}{l}5.0 \\
2.6\end{array}$ \\
\hline
\end{tabular}

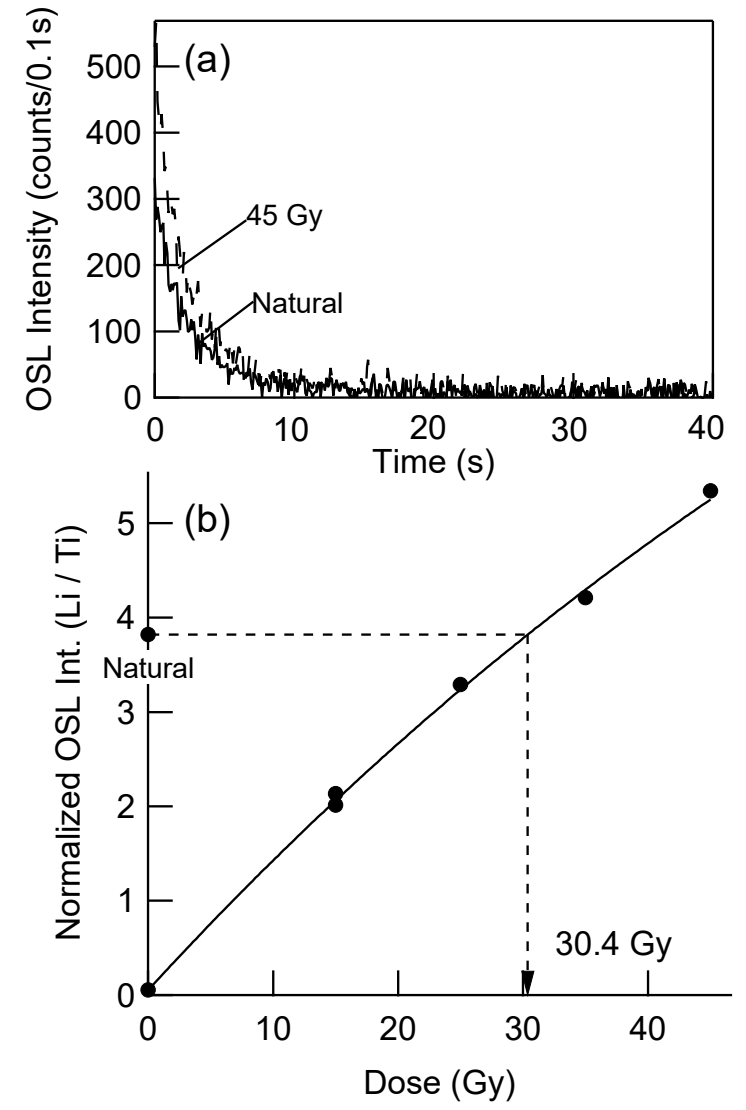

Fig. 7. a) OSL decay curve of natural and 45 Gy as regeneration dose. b) Growth curve of an aliquot for regenerative doses of 0, 15, 25, 35, and $45 \mathrm{~Gy}$.

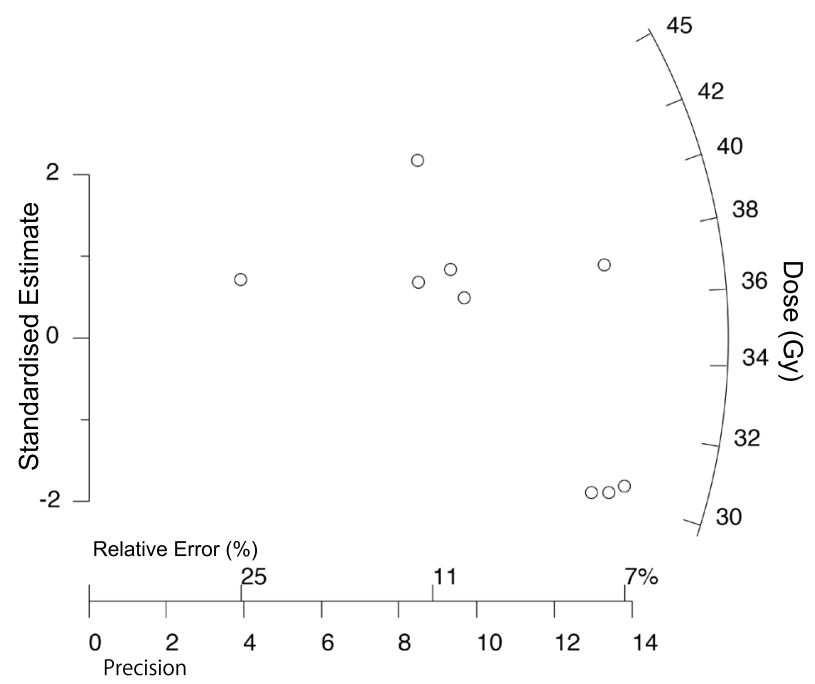

Fig. 8. Dose distributions $(n=9)$ are shown as the radial plots.

9.2\%. Following procedures reported by Olley et al. (2004), a sedimentary sample with overdispersion of less than $20 \%$ was fully bleached. Presumably, this sample was well-bleached sediment. The paleodose of the sample was calculated using the central age model (Galbraith et al., 1999; Vermeesch, 2009).

The OSL age, $21 \pm 6 \mathrm{ka}$, is presented in Table 3. This result is consistent with tephrostratigraphy of the period between $c a$. 7.2-7.3 and $c a .30 \mathrm{ka}$. 
Table 3. Results of OSL dating.

\begin{tabular}{cccccccc}
\hline $\begin{array}{c}\text { Paleodose } \\
(\mathrm{Gy})\end{array}$ & $\begin{array}{c}\text { Aliquots } \\
(\mathbf{n})\end{array}$ & $\begin{array}{c}\mathrm{U} \\
(\mathbf{p p m})\end{array}$ & $\begin{array}{c}\text { Th } \\
(\mathrm{ppm})\end{array}$ & $\begin{array}{c}\mathrm{K} \\
(\mathbf{w t} \%)\end{array}$ & $\begin{array}{c}\text { Water content } \\
(\%)\end{array}$ & $\begin{array}{c}\text { Annual dose } \\
(\mathrm{mGy} / \mathrm{a})\end{array}$ & $\begin{array}{c}\text { OSL age } \\
(\mathbf{k a})\end{array}$ \\
\hline $34.7 \pm 1.6$ & $9 / 15$ & $1.25 \pm 0.09$ & $8.26 \pm 0.42$ & $0.74 \pm 0.05$ & $62 \pm 6$ & $1.62 \pm 0.42$ & $21 \pm 6$ \\
\hline
\end{tabular}

$n$ is the number of individual aliquots contributing to paleodose estimation against the number of aliquots measured.

\section{DISCUSSION}

We investigated the eruption age of the Kannabe volcano in Japan. The Kannabe scoria lies between widespread tephras of K-Ah (ca 7.2-7.3 ka) and AT ( $c a .30 \mathrm{ka}$ ) (Fig. 2). The OSL dating indicates the age of the clay bank soil layer overlying the Kannabe scoria as $21 \pm 6 \mathrm{ka}$. These data suggest that the eruption age of the Kannabe scoria lies between $c a .21$ and $30 \mathrm{ka}$.

The paleomagnetic age was estimated by comparing our results with PSV data obtained from Lake Biwa sediments (Hayashida et al., 2007). Lake Biwa is nearby: about $120 \mathrm{~km}$ east of the studied area. The PSV from Lake Biwa has a high temporal resolution for the past 40 ka. Consequently, the PSV is potentially applicable for estimating the paleomagnetic age of Kannabe lava. According to OSL dating, the Kannabe volcano eruption is estimated to have occurred before $21 \pm 6 \mathrm{ka}$. AT tephra underlying the Kannabe scoria indicates that its eruption occurred after $30 \mathrm{ka}$. Therefore, PSV during 20-30 ka was compared with our data. Inclination of the PSV does not reach $60^{\circ}$ during $20-30 \mathrm{ka}$, despite our results indicating $65.9^{\circ}$ (Fig. 9). The PSV data is derived from detrital remanent magnetization, which can be affected by smoothing effect on the magnetic signal. The amplitudes of the $40 \mathrm{ka}$ PSV data seem to be attenuated compared to the Holocene PSV data, which has a 2.5 times higher sedimentation rate (Hayashida et al., 2007). A short-term variation may disappear in the $40 \mathrm{ka}$ PSV data. Also, inclination error (e.g. Dunlop and Özdemir, 1997) possibly occurs in the $40 \mathrm{ka}$ PSV data because the average inclination for $4-23 \mathrm{ka}$ is about $6^{\circ}$ shallower than the geocentric axial dipole field (Hayashida et al., 2007). Therefore, we sought the period showing steep inclination from the PSV from Lake Biwa. During 20-30 ka, two peaks in steep inclination with more than $50^{\circ}$ are apparent at $c a .21 .5 \mathrm{ka}$ and $c a .25 \mathrm{ka}$ (Fig. 9). Declination of the PSV at $c a$. $21.5 \mathrm{ka}$ is about $-1^{\circ}$, which closely approximates our results of $0.3^{\circ}$, whereas that at $c a .25 \mathrm{ka}$ is about $7-29^{\circ}$. Therefore, the paleomagnetic age of Kannabe lava is estimated as ca $21.5 \mathrm{ka}$.

Within the age range, the remanent magnetization (declination and inclination) of the Kannabe lava accords exactly with the environmental magnetic record at around $22 \mathrm{ka}$. Consequently, we can infer the eruption age of the Kannabe scoria cone as $c a .22 \mathrm{ka}$.

\section{SUMMARY}

Identification of active volcanoes is extremely important not only for volcanology but also for disaster prevention. A method for precise age determination of young volcanic rocks must be established. In this study, the eruption age of young basaltic lava was ascertained using paleomagnetic dating, OSL dating, and tephrochronology. Tephrochronological estimation results indicate to us that the eruption occurred between 7.2-7.3 and $30 \mathrm{ka}$. The OSL age of sediment on Kannabe scoria was

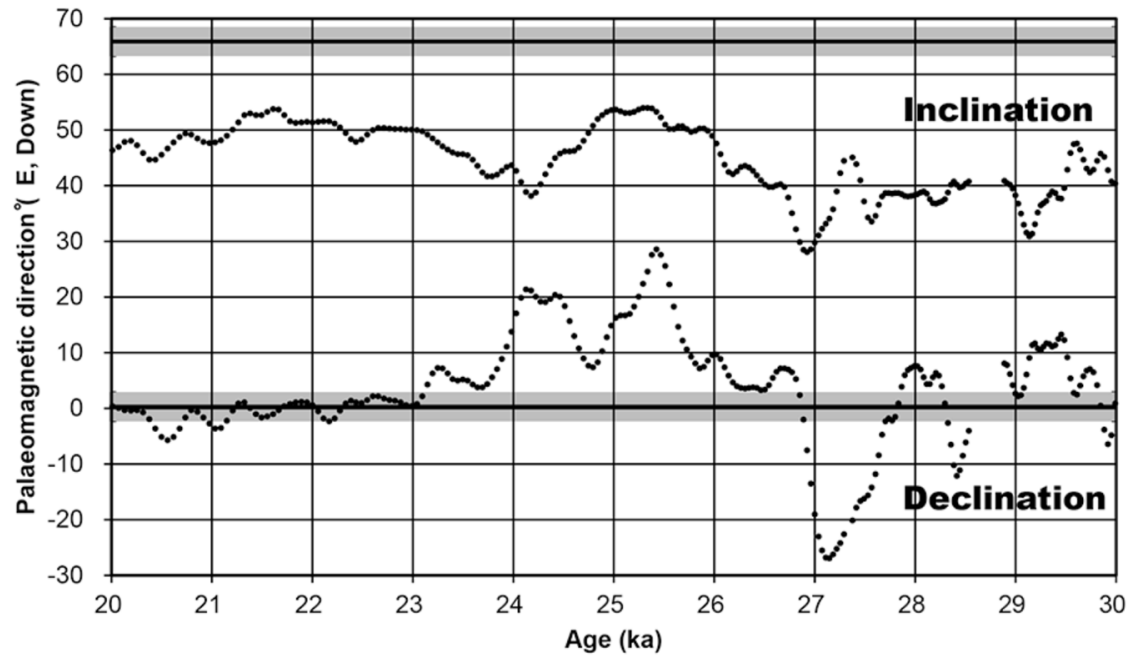

Fig. 9. Paleomagnetic direction from Kannabe lava shown on paleosecular variations from Lake Biwa after Hayashida et al. (2007). Bold lines and gray bars respectively represent the paleomagnetic direction and its $95 \%$ confidence angle. 
$21 \pm 6 \mathrm{ka}$. The paleomagnetic age was found to be $c a$. 21.5 ka by comparison with PSV from Lake Biwa. Consequently, the eruption age of Kannabe volcano is inferred as $c a .22 \mathrm{ka}$.

This study demonstrated that multi-method dating is an effective tool for the age determination of young volcanic rocks.

\section{ACKNOWLEDGMENTS}

We wish to thank Drs. A. Hayashida and H. Morinaga, who provided data and many useful comments to us, and to Madoka Miyoshi for her help with fieldwork. This study was funded by a grant of San'in Kaigan Geo Park, and was partially supported by Grants-in-Aid for Young Scientists (A) and (B) from the Japan Society for the Promotion of Science (No. 25702011 and No. 23701012).

\section{REFERENCES}

Duller GAT, 2007. Assessing the error on equivalent dose estimates derived from single aliquot regenerative dose measurements. Ancient TL 25: 15-24.

Dunlop DJ and Özdemir Ö, 1997. Rock Magnetism: Fundamentals and frontiers. 573 pp, Cambridge University Press, Cambridge.

Furuyama K, 1973. Volcanostratigraphy of the Kannabe Volcano Group. The Journal of the Geological Society of Japan 79: 399406 (in Japanese with English abstract).

Furuyama K, Nagao K, Kasatani K and Mitsui S, 1993. K-Ar ages of the Kannabe Volcano Group and the adjacent basaltic monogenetic volcanoes, east San-in district. Earth Science 47: 377-390 (in Japanese with English abstract).

Galbraith RF, Roberts RG, Laslett GM, Yoshida H and Olley JM, 1999. Optical dating of single and multiple grains of quartz from Jinmium rock shelter, northern Australia: part 1, experimental design and statistical models. Archaeometry 41: 339-364, DOI 10.1111/j.1475-4754.1999.tb00987.x.

Guérin G, Mercier N and Adamiec G, 2011. Dose-rate conversion factors: update. Geochronometria 29: 5-8.

Hayashida A, Ali M, Kuniko Y, Kitagawa H, Torii M and Takemura K, 2007. Environmental magnetic record and paleosecular variation data for the last 40 kyrs from Lake Biwa sediments, Central Japan. Earth Planets Space 59: 807-814, DOI 10.1186/BF03352743.

Jackson A and Finlay CC, 2007. Geomagnetic Secular Variation and Its Applications to the Core. in Geomagnetism, Olson P and Schubert G (Eds.): 147-193.

Kawamoto T, 1990. Geology of the Kannabe Monogenetic Volcano Group, Southwest Japan. Kazan 35: 41-56 (in Japanese with English abstract).

Kimura J, Stern RJ and Yoshida T, 2005. Reinitiation of subduction and magmatic responses in SW Japan during Neogene time. GSA Bulletin 117: 969-986, DOI 10.1130/B25565.1.

Kirschvink JL, 1980. The least-squares line and plane and the analysis of paleomagnetic data. Geophysical Journal of the Royal Astronomy Society 62: 699-719, DOI $10.1111 / \mathrm{j} .1365-$ 246X.1980.tb02601.x.

Morinaga H, Matsumoto T, Okimura, Y and Matsuda T, 2000. Paleomagnetism of Pliocene to Pleistocene lava flows in the northern part of Hyogo prefecture, Southwest Japan and Brunhes Chron paleosecular variation in Japan. Earth Planets Space, 52: 437-443, DOI 10.1186/BF03352255.

Murray AS and Wintle AG, 2000. Luminescence dating of quartz using an improved single-aliquot regenerative-dose protocol. Radiation Measurements 32: 57-73, DOI 10.1016/S1350-4487(99)00253-X.

Nagatomo T, Shitaoka Y and Kunikita D, 2007. IRSL Dating of the Sediments at the Neolithic Sites in the Russian Far East. Bulletin of Nara University of Education 56: 1-6 (in Japanese with English abstract).

Nagatomo T, Shitaoka Y, Namioka H, Sagawa M and Wei Q, 2009. OSL Dating of the Strata at Paleolithic Sites in the Nihewan Basin, China. Acta Anthropologica Sinica 28: 276-284 (in English and Chinese).

Nakajima $J$ and Hasegawa A, 2007. Tomographic evidence for the mantle upwelling beneath southwestern Japan and its implications for arc magmatism. Earth Planets Science Letters 254: 90-105, DOI 10.1016/j.eps1.2006.11.024.

Olley JM, Deckker PD, Roberts RG, Fifield LK, Yoshida H and Hancock G, 2004. Optical dating of deep-sea sediments using single grains of quartz: a comparison with radiocarbon. Sedimentary Geology 169: 175-189, DOI 10.1016/j.sedgeo.2004.05.005.

Prescott JR and Hutton JT, 1994. Cosmic ray contributions to dose rates for luminescence and ESR dating: Large depths and long-term time variations. Radiation Measurements 23(2-3): 497-500, DOI 10.1016/1350-4487(94)90086-8.

Rufer D, Gnos E, Mettier R, Preusser F and Schreurs G, 2012. Proposing new approaches for dating young volcanic eruptions by luminescence methods. Geochronometria 39: 48-56, DOI 10.2478/s13386-011-0049-y.

Shitaoka Y, Nagatomo T and Obata N, 2009. Age determination of Ontake Pm1 pumice fall deposit (On-Pm1) by thermoluminescence method. The Quaternary Research 48: 295-300 (in Japanese).

Shitaoka Y and Nagatomo T, 2013. OSL dating using quartz fine grains extracted from Loess in Upper Palaeolithic sites of Nihewan Basin, Northern China. Geochronometria 40: 311-316, DOI 10.2478/s13386-013-0123-8.

Shitaoka Y, Miyoshi M, Yamamoto J, Shibata T, Nagatomo T and Takemura K, 2014. Thermoluminescence age of quartz xenocrysts in basaltic lava from Oninomi monogenetic volcano, northern Kyushu, Japan. Geochronometria 41: 30-35, DOI 10.2478/s13386-013-0144-3.

Smith VC, Staff RA, Blockley SPE, Ramsey CB, Nakagawa T, Mark DF, Takemura K, Danhara T and Suigetsu 2006 Project Members, 2013. Identification and correlation of visible tephras in the Lake Suigetsu SG06 sedimentary archive, Japan: chronostratigraphic markers for synchronising of east Asian/west Pacific palaeoclimatic records across the last $150 \mathrm{ka}$. Quaternary Science Reviews 67: 121-137, DOI 10.1016/j.quascirev.2013.01.026.

Torii M, Otofuji Y, Nakajima M, Natsuhara N, Sato T, Hirooka K and Furuyama K, 1978. Palaeomagnetism of Kannabe volcanic group. $63 \mathrm{rd}$ Meeting of Society of Terrestrial Magnetism and Electricity of Japan: 153. (in Japanese)

Tsukamoto S, Duller GAT, Wintle AG and Muhs D, 2011. Assessing the potential for luminescence dating of basalts. Quaternary Geochronology 6: 61-70, DOI 10.1016/j.quageo.2010.04.002.

Vermeesch P, 2009. RadialPlotter: A Java application for fission track, luminescence and other radial plots. Radiation Measurements 44(4): 409-410, DOI 10.1016/j.radmeas.2009.05.003.

Wadatsumi K and Matsumoto T, 1958. The Stratigraphy of the Neogene Formations in Northern Tazima - Study of the Neogenein the Northwest Part of the Kinki District - (Part 1). The Journal of Geological Society of Japan 64: 625-637 (in Japanese with English abstract).

Wintle AG and Murray AS, 2006. A review of quartz optically stimulated luminescence characteristics and their relevance in singlealiquot regeneration dating protocols. Radiation Measurements 41: 369-391, DOI 10.1016/j.radmeas.2005.11.001.

Zijderveld JDA, 1967. A.C. demagnetization of rocks: Analysis of results. in Methods in Palaeomagnetism, Collinson DW, Creer KM and Runcorn SK (Eds.): 254-286. 